Reprod. Nutr. Dévelop., 1985, 25 (6), 1037-1046.

\title{
Determination of assay parameters for RNA analysis in bacterial and duodenal samples by spectrophotometry. Influence of sample treatment and preservation
}

\author{
K. USHIDA $(*)$, Bernadette LASSALAS, J.-P. JOUANY
}

Laboratoire de la Digestion des Ruminants, I.N.R.A., Theix, 63122 Ceyrat, France.

(*) Department of animal Science, College of Agriculture, Kyoto University, Kyoto, Japan 606.

Summary. A simple analytical procedure derived from that described by Zinn and Owens (1980), based on the determination of nucleic purine bases (RNA eq), was carried out to measure microbial nitrogen flow in the ruminant duodenum. Several procedures for sample preservation were tested ; the efficiency of each step of the analytical method was also determined using high performance liquid chromatography (HPLC). The proposed method (RNA eq) was compared with two other methods considered as references (2-6 diaminopimelic acid and ${ }^{35} \mathrm{~S}$ incorporation) and microbial nitrogen flow was measured in defaunated sheep.

The recovery of purine bases analysed by the Zinn and Owens method was generally good (101\% pure bases ; $90 \%$ when bases were added to bacterial samples ; $96 \%$ when added to yeast RNA).

The HPLC measurements allowed us to conclude that this spectrophotometric method is specific for purine bases, all pyrimidine bases being eliminated. Moreover, it was found that the method must be used on freeze-dried samples; storage at $+4{ }^{\circ} \mathrm{C}$, defatting or freezing gave incorrect results. Using the described assay, we observed that microbial nitrogen flow at the duodenum of defaunated sheep was not significantly different from that obtained using more traditional markers such as sulphur-35 incorporation or diaminopimelic acid.

\section{Introduction.}

The utilization of nucleic acids as a marker for quantifying microbial synthesis in the rumen was first suggested by Gausseres and Fauconneau (1965). A series of studies on the utilization of this marker was completed by McAllan and Smith $(1969,1972,1973,1983,1984)$ in which these authors reported its advantages and disadvantages. The analytical procedure for determining acids is so long and laborious that it is difficult to apply this method to trials which provide large quantities of samples. Some workers use a simpler analytical procedure (Topps and Elliott, 1965) or determine nucleic acid purine bases (McDonald, 1954). However, McAllan and Smith (1969) pointed out that these 
methods are less reliable due to the presence of interfering substances. In 1980, Zinn and Owens proposed an analytical procedure for estimating nucleic acid purine bases which seems to be both simple and efficient : an oxidative hydrolysis releases the bases which are then precipitated by forming an $\mathrm{AgNO}_{3}$-purine complex at a pH between 2 and 3 . The precipitate, washed to eliminate the pyrimidine bases, is solubilized, with heating, at a $\mathrm{pH}$ below 2 . The optical density of the purine bases is read at $260 \mathrm{~nm}$. RNA eq is determined using yeast RNA as the RNA standard. The procedure, however, was published only as a simple diagram which did not provide all the information necessary to use it.

Recently, Ha and Kennelly (1984), reporting some results on sample treatment with the method of Zinn and Owens, indicated that, in contrast to RNA analysis, sample freezing and thawing did not have any effect on purine base determination. The present paper reports an analytical method for purine bases, using the diagram of Zinn and Owens in which the efficiency of oxidative hydrolysis of nucleic acid, the release of purine bases and their precipitation as silver salts were all verified by high-performance liquid chromatography (HPLC). The best procedure for sample preservation and treatment prior to analysis for bacteria and duodenal digesta was also investigated. The daily flow of microbial nitrogen at the duodenum was estimated using the ratio nitrogen : purine bases in bacteria to the concentration of purine bases in duodenal digesta. These estimates were then compared with those given by 2-6 diaminopimelic acid (DAP) and sulfur-35 $\left({ }^{35} S\right)$ incorporation which were considered to be the reference values that allowed selection of the best method of sample treatment and preservation for purine base analysis when estimating rumen microbial synthesis. The three methods (DAP, ${ }^{35} \mathrm{~S}$ and purine bases) were compared in defaunated animals to eliminate any possible interference from protozoa.

\section{Material and methods.}

1. Animals and diets. - Six adult wether sheep, fitted with rumen fistula and simple duodenal cannula were used. They were defaunated prior to the experiment as described by Jouany and Senaud (1979). Three sheep received a diet (L) composed of lucerne hay (66 \%), barley (31\%) and wheat straw (3\%), while the other sheep received a diet (S) composed of $\mathrm{NaOH}$-treated wheat straw $(68 \%)$, sugar beet pulp (15\%), soybean meal $(5 \%)$, peanut cake meal $(9 \%)$, urea $(1 \%)$ and a vitamin-mineral premix $(2 \%)$. Both diets were pelleted and distributed $(150 \mathrm{~g})$ at 3 -hour intervals by means of an automatic feeder. Water was always available.

Rumen contents and duodenal digesta were sampled as described by Thivend and Jouany (1983). The digesta flow was estimated using chromium mordanted lucerne hay as a marker for both diets, prepared as described by Uden et al. (1980). A solution of $\mathrm{Na}_{2}{ }^{35} \mathrm{SO}_{4}$ was infused into the rumen via the rumen fistula at the rate of $250 \mu \mathrm{Ci}$ per animal per day. The infusion was started 3 days before duodenal sampling. 
2. Analytical procedure. - Two methods were used to determine the nucleic acid purine bases :

1) the spectrophotometric method was carried out to determine the concentration of " equivalents of yeast RNA " (RNA eq) in the different samples of bacteria and digesta (diagram 1). This part of the experiment was used to determine some aspects of the method, such as filter pore size, speed and time of centrifugation and elimination of interfering substances, which were not reported in the original paper of Zinn and Owens (1980) ;

\section{Diagram 1 :}

Method of purine base analysis for rumen bacteria and intestinal digesta.

Step :

1) Weigh $0.5 \mathrm{~g}$ of freeze-dried sample into $30 \mathrm{ml}$ test tube with screw cap.

2) Add $3 \mathrm{ml}$ of $70 \% \mathrm{HClO}_{4}$ and hydrolyse for 1 hour in $95{ }^{\circ} \mathrm{C}$ water bath.

3) Add $17.5 \mathrm{ml}$ of $0.0285 \mathrm{M} \mathrm{NH}_{4} \mathrm{H}_{2} \mathrm{PO}_{4}$ and mix thoroughly and then place in $95^{\circ} \mathrm{C}$ water bath for an additional $15 \mathrm{~min}$.

4) Filter hydrolysate through a glass filter $\left(n^{\circ} 5\right)$.

5) Mix $0.5 \mathrm{ml}$ of filtrate, $0.5 \mathrm{ml}$ of $0.4 \mathrm{M} \mathrm{AgNO}_{3}$ and $9 \mathrm{ml}$ of $0.2 \mathrm{M} \mathrm{NH}_{4} \mathrm{H}_{2} \mathrm{PO}_{4}$ in a centrifuge tube. Allow to stand for $30 \mathrm{~min}$.

6) Centrifuge at $25,000 \times \mathrm{g}$ for $15 \mathrm{~min}$.

7) Wash pellet with $10 \mathrm{ml}$ of $0.2 \mathrm{M} \mathrm{NH}_{4} \mathrm{H}_{2} \mathrm{PO}_{4}$ adjusted to $\mathrm{pH} 2$ with conc. $\mathrm{H}_{2} \mathrm{SO}_{4}$ and centrifuge at $25,000 \times \mathrm{g}$ for $15 \mathrm{~min}$.

8) Add $10 \mathrm{ml}$ of $0.5 \mathrm{~N} \mathrm{HCl}$ to the pellet and mix thoroughly. Place in $95^{\circ} \mathrm{C}$ water bath for $30 \mathrm{~min}$.

9) Filter with a coarse filter paper.

10) Read at $260 \mathrm{~nm}$.

The purine base standard curve is established using yeast RNA $(60 \mathrm{mg})$ which has undergone all these steps. The filtrate of step 9 is successively diluted using $0.5 \mathrm{~N} \mathrm{HCl}$.

2) an HPLC study was carried out using the method described by Schweinsberg and $\mathrm{Ti}$ Li Loo (1980) for the analysis of nucleotides which was modified to analyse purine bases released from nucleic acid by perchloric acid hydrolysis. The purine bases were analysed by HPLC $24 \mathrm{~h}$ after RNA eq determination. Solutions injected into the chromatograph were first brought to $\mathrm{pH} 12$ with $12 \mathrm{~N} \mathrm{NaOH}$ to solubilize those purine bases (mainly guanine) which precipitate at a $\mathrm{pH}$ of less than 2 after standing overnight. This study served to verify the efficiency of nucleic acid hydrolysis, the efficiency of purine base silver salt complexation, and the recovery rate of purine bases without the pyrimidine base contamination occurring in the Zinn and Owens method.

Other markers. - Chromium was determined by the method of Mathieson (1970). ${ }^{35} \mathrm{~S}$ was determined as described by Mathers and Miller (1980), while DAP was analysed using ion-exchange chromatography (Collombier, 1981).

3. Treatment and preservation of samples prior to analysis. - According to McAllan and Smith (1969, 1983), sample treatment and preservation have an important effect on RNA analysis since the concentration of RNA-N in bacterial preparations can change from 9.89 to $4.02 \mathrm{mg} / \mathrm{g}$ DM according to the method of 
sample preservation. The RNA-N content of duodenal samples is less affected by different treatments. Based on these published results and on the hypothesis of these authors, each sample of bacteria was divided into four parts and each part was allotted to one of four treatments : (1) storage for $72 \mathrm{~h}$ at $4{ }^{\circ} \mathrm{C},(2)$ addition of $37 \% \mathrm{HCl}$ acid until $\mathrm{pH} 2$ and then storage at $-20{ }^{\circ} \mathrm{C}$ from 96 to $144 \mathrm{~h}$, (3) fat extraction according to the method of McAllan and Smith (1969) (2nd to 6th step of their method), (4) thinly spread in an aluminium tray and frozen at $-20^{\circ} \mathrm{C}$, then freeze-dried. Each sample of duodenal digesta was divided into three parts and each part was allotted to one of the following treatments : a) storage at $-20^{\circ} \mathrm{C}$ and direct determination, b) fat extraction, c) freeze-drying. For the wet samples $(1,2, \mathrm{a}), 3 \mathrm{~g}$ of the bacterial sample and $5 \mathrm{~g}$ of the duodenal sample were hydrolysed with perchloric acid, while $0.5 \mathrm{~g}$ of sample was used for the dry samples $(3,4, b, c)$.

4. Comparison of different methods for determining microbial synthesis. - Bacterial nitrogen flow at the duodenum was calculated using the three different marker methods in defaunated sheep. Defaunating the sheep permitted these three methods to be compared.

All results were treated statistically by analysis of variance.

\section{Results and discussion.}

\section{Alterations in the original method of Zinn and Owens (1980).}

We have indicated the conditions for filtration (step 4) and centrifugation (steps 6 and 7) and have added one other step (9) in diagram 1.

Step 4 : different types of filters (paper or glass) and different pore sizes were tested. Filtration using $n^{\circ} 5$ glass filters with vacuum eliminated all the black solid particles present in the liquid after oxidation. Perchloric acid, however, reacted with the glass filters which had to be changed every 100 samples.

Steps 6 and 7 : the recovery rate of the "Ag-purine " complex by centrifugation must be quantitative. Our study shows that this condition was reached with $25,000 \times \mathrm{g}$ for $15 \mathrm{~min}$.

Step 9 : many fine particles (probably chlorides) were present in the liquid containing purine bases when the "Ag-purine " complex was dissolved in step 8 . These particles sometimes interfered with the spectrophotometric determinations of some duodenal samples, giving incorrect values for RNA eq (50\% too high). Filtration with coarse paper (step 9) eliminated interference, so this step was added for the analysis of all samples. Under the conditions used, the method gave reproducible results (on a microbial nitrogen basis) equal to those obtained with ${ }^{35} \mathrm{~S}$ and DAP.

2. Verification of the validity of the Zinn and Owens method by HPLC (table 1).

When pure adenine or guanine was analysed as shown in diagram 1, adenine and guanine recoveries were 101.1 and $101.6 \%$, respectively ; when each purine 
base was added to a bacterial sample, adenine and guanine recoveries were 90.9 and $90.6 \%$, respectively. Under the same conditions, the recovery of the purine bases in yeast RNA added to bacterial samples was $96.4 \%$. These results suggest that the oxidative hydrolysis of nucleic acid was complete, that the precipitation of purine bases as silver salts and their solubilization were also complete. The HPLC measurements allow us to conclude that pyrimidine bases were totally eliminated at step 10 after washing the precipitate and centrifugation (step 7) (diagram 1). Finally, the adenine/guanine ratio determined in bacteria isolated from the rumen of 11 different sheep (1.41 \pm 0.08$)$ was not significantly different from the same ratio measured in yeast RNA $(1.32 \pm 0.03)$. This result shows that purine base composition in yeast RNA, used as a standard, corresponds to that of rumen bacteria.

After verifying the validity of the RNA eq analysis, we measured the influence of sample treatment and preservation on microbial synthesis estimated with this method.

TABLE 1

Recovery rate of adenine and guanine determined by HPLC ( $\left.{ }^{1}\right)$.

\begin{tabular}{lcc}
\hline & $\begin{array}{c}\text { Weight of additional } \\
\text { purine base }(\mathrm{mg})\end{array}$ & $\begin{array}{c}\text { Recovery rate of } \\
\text { purine base }(\%)\left({ }^{2}\right)\end{array}$ \\
\hline Adenine & 8.0 & $101 \pm 2.7$ \\
Guanine & 3.0 & $101 \pm 2.7$ \\
Bacteria + adenine & 8.0 & $90.0 \pm 1.9$ \\
Bacteria + guanine & 3.0 & $90.6 \pm 1.9$ \\
Bacteria + yeast RNA & 45.0 & $96.4 \pm 11.1$
\end{tabular}

(1) The solution of step 10 (diagram 1), analysed by HPLC, was adjusted to $\mathrm{pH} 12$ by $12 \mathrm{~N} \mathrm{NaOH}$ prior to analysis.

(2) Means \pm s.d.

\section{Sample treatment and preservation.}

Sample treatment and preservation have a significant effect on purine base concentration.

Of the four treatments (table 2), the freeze-dried and fat-extracted samples of bacteria showed the highest purine base concentration. Purine base losses (approximately $10 \%$ ) were low when bacterial samples were frozen and stored at $-20^{\circ} \mathrm{C}$ for 14 days. These losses reached a high level $(37 \%)$ when bacterial samples were stored at $+4{ }^{\circ} \mathrm{C}$ for $72 \mathrm{~h}$.

As for bacterial samples, the method of treatment and preservation of duodenal digesta had an important effect on the results of purine bases measurements. The concentrations of purine bases (RNA eq) in freeze-dried digesta or in samples stored at $-20^{\circ} \mathrm{C}$ were 2 and 3 times higher, respectively, than those in fat-extracted digesta (table 3). The purine bases of digesta samples stored at $+4{ }^{\circ} \mathrm{C}$ were not determined because $+4{ }^{\circ} \mathrm{C}$ storage was shown to allow large losses in the bacteria samples which could be explained by enzymatic 


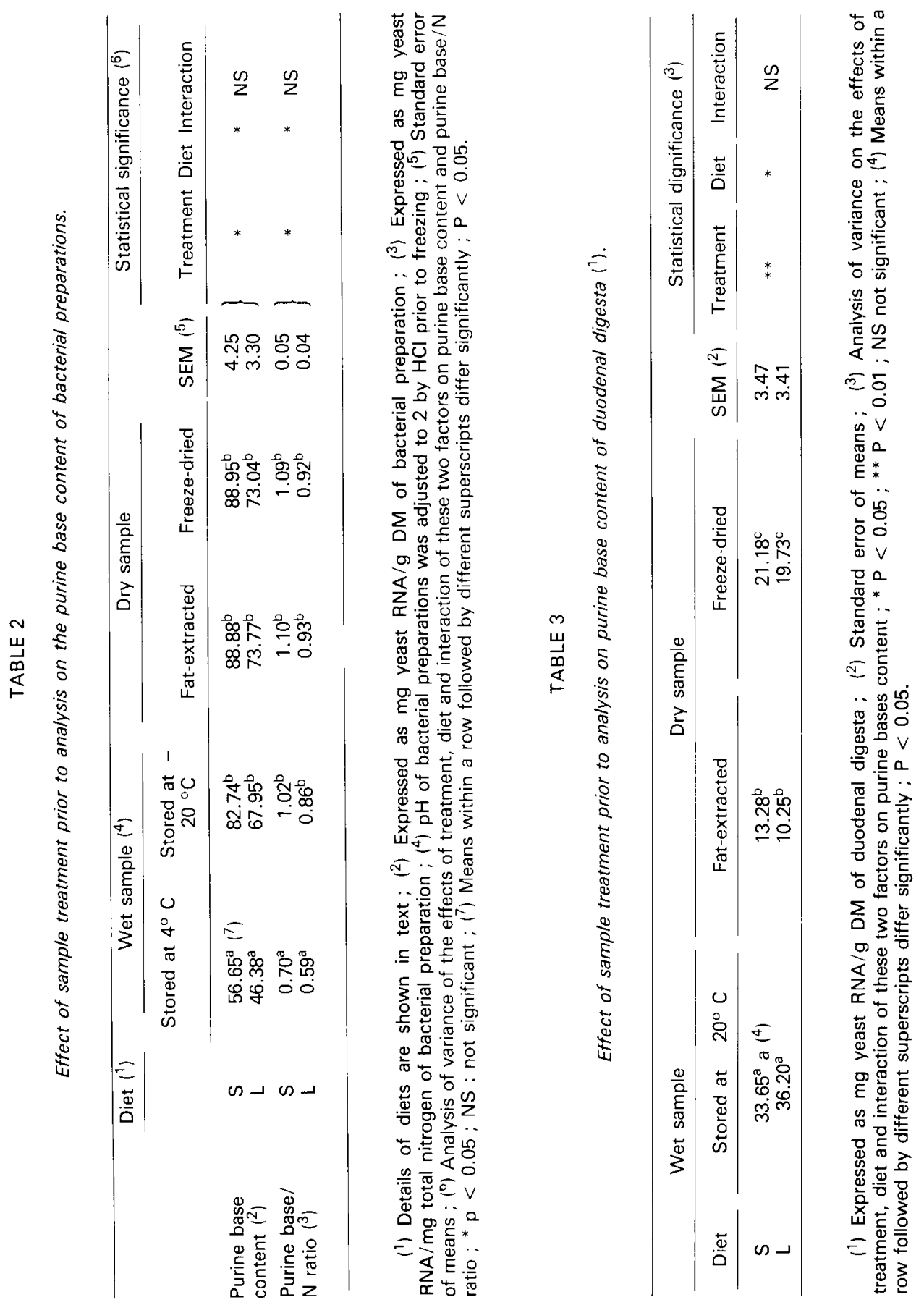


degradation of free purine bases. The most suitable method of preservation for both bacterial and digesta samples was determined by comparing the estimates of bacterial nitrogen flow at the duodenum; these results were obtained by three different markers : RNA eq, ${ }^{35}$ S and DAP (table 4). Considering the results when ${ }^{35} \mathrm{~S}$ or DAP measurements were used as reference values, it appears that samples of bacteria and duodenal digesta should be stored in the freeze-dried form since the differences found between the different marker methods were not significant in that case. The microbial nitrogen flow determined from RNA eq on fat-extracted or frozen samples was always significantly different from the other three methods tested $\left({ }^{35} \mathrm{~S}, \mathrm{DAP}\right.$ and RNA eq on freeze-dried samples). Fat extraction lowered the microbial nitrogen flow, while freezing wet samples gave excessively high values.

The abnormal values obtained with the wet duodenal or bacterial samples could be due to several factors : the water in the wet samples diluted the perchloric acid $(7 \mathrm{~N})$ used for nucleic acid hydrolysis to $2.7 \mathrm{~N}$ in the wet digesta and to $5.8 \mathrm{~N}$ in the wet bacterial samples. Moreover, the samples hydrolysed in this study were rich in organic matter which would utilize an unknown proportion of the added perchloric acid for its digestion. These losses would limit the true amount of perchloric acid available for nucleic acid hydrolysis in the wet samples, although Loring (1955) reported that $1 \mathrm{~N}$ acid was sufficient to release all the purine bases in nucleic acid. The water content also caused an increase in the hydrolysate volume at step 4 and thus decreased the concentration of purine bases in the aliquot $(0.5 \mathrm{ml})$ taken at step 5 . The abnormally high values obtained with wet duodenal samples compared to dry samples may therefore be due to their water content. This hypothesis is confirmed by the following results. When $5 \mathrm{ml}$ of water were added to $0.5 \mathrm{~g}$ of freeze-dried duodenal samples taken from 3 faunated sheep fed the (S) diet, RNA eq values were similar to those obtained with wet samples $(30.12 \pm 1.99$ and $29.30 \pm 1.12 \mathrm{mg}$ RNA eq/g DM of duodenal digesta, respectively vs $14.02 \pm 0.80$ for freeze-dried samples). These results suggest that dilution of perchloric acid induces an incomplete elimination of the interfering substances which have a strong absorbance at $260 \mathrm{~nm}$. Thus, it is essential to utilize dry samples with this method. This observation does not agree with the results of $\mathrm{Ha}$ and Kennelly (1984) who found no modification in the purine base content of frozen samples after a 2-week period of preservation.

The method proposed in diagram 1, with some modifications of the original method of Zinn and Owens (1980), can be used to determine the "RNA eq " in rumen bacteria and duodenal digesta. This method gives estimates of rumen microbial nitrogen flow at the duodenum which are not significantly different from those obtained using more traditional markers such as ${ }^{35} \mathrm{~S}$ or DAP. The use of purine bases for estimating microbial synthesis in the rumen is not valid, however, when dietary RNA or purine bases flow into the duodenum, and this problem still remains to be solved. 


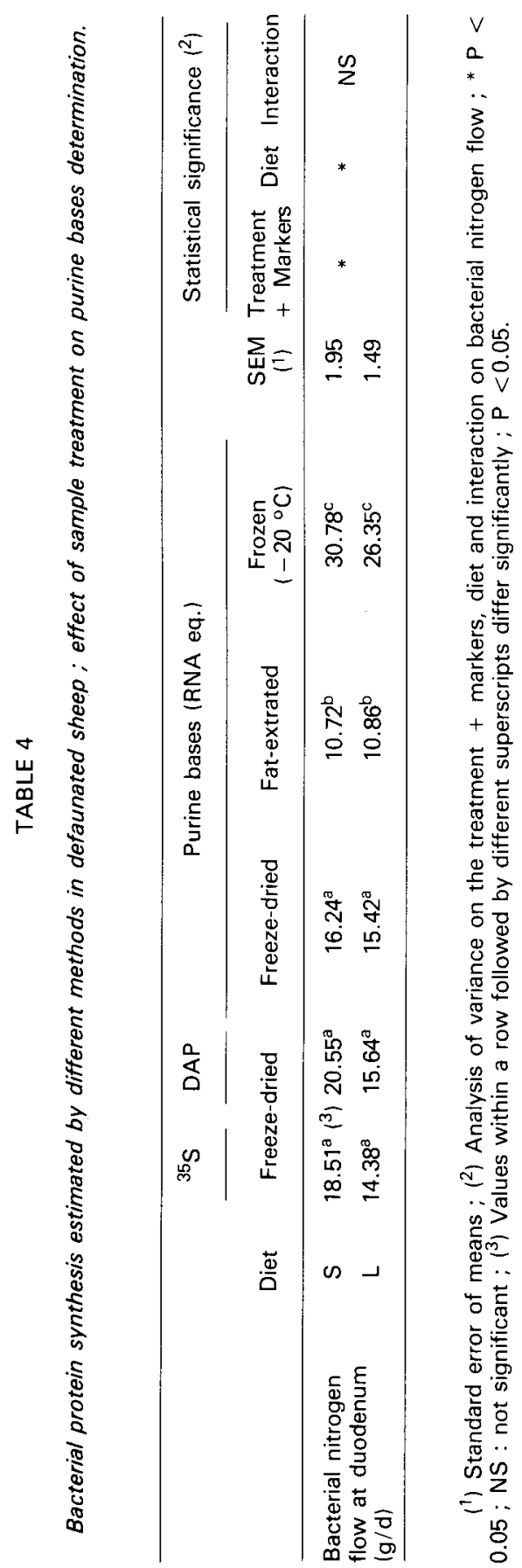


Résumé. Etude d'une méthode spectrophotométrique de dosage de l'ARN des bactéries du rumen et des contenus duodénaux; influence du traitement et de la conservation des échantillons.

Nous avons étudié la validité de chaque étape du dosage de I'ARN par la méthode de Zinn et Owens (1980) utilisée pour estimer le flux d'azote microbien dans le duodénum du ruminant. Plusieurs procédés de conservation des échantillons ont été testés. L'efficacité de chaque étape de la méthode a été vérifiée en dosant les bases puriques par HPLC. La méthode proposée (RNA eq), plus détaillée que celle décrite par Zinn et Owens, a été comparée à deux autres méthodes de marquage de l'azote microbien considérées comme des références (DAP et ${ }^{35} \mathrm{~S}$ ). Les flux d'azote microbien ont été mesurés sur des animaux défaunés pour que les 3 méthodes puissent être comparées.

Le taux de récupération des surcharges en bases puriques étaient généralement bon $1101 \%$ sur les bases pures, $90 \%$ lorsque les bases étaient ajoutées à des échantillons bactériens, et $96 \%$ lorsqu'elles étaient additionnées à du RNA de levure).

Les analyses par HPLC ont montré que cette méthode spectrophotométrique est bien spécifique des bases puriques, l'ensemble des bases pyrimidiques ayant été éliminées au cours de la phase de complexation au sel d'argent. En outre, nous avons constaté que la conservation des échantillons devait impérativement être faite par lyophilisation. Dans ces conditions, le flux d'azote microbien déterminé chez le mouton par dosage de l'ARN n'a pas été significativement différent de ceux calculés à partir de marqueurs traditionnels que sont le DAP et le ${ }^{35} \mathrm{~S}$.

\section{Références}

COLLOMBIER J., 1981. Contribution à l'étude du rôle des protozoaires ciliés du rumen dans l'apport $d^{\prime}$ azote microbien entrant dans le duodénum des ruminants. Th. Doc. Ing. Uni. Clermont II. $N^{\circ}$ d'ordre 105.

GAUSSERĖS B., FAUCONNEAU G., 1965. Evaluation quantitative à l'aide de sa teneur en acides nucléiques, de la population microbienne du tube digestif des ruminants. Ann. Biol. anim. Biochim. Biophys. 5, 5-20.

HA J. K., KENNELLY J. J., 1984. Influence of freeze-storage on nucleic acid concentrations in bacteria and duodenal digesta. Can. J. anim. Sci., 64, 791-793.

JOUANY J. P., SENAUD J., 1979. Défaunation du rumen de mouton. Ann. Biol. anim. Biochim. Biophys., 19, 619-624.

LORING H. S., 1955. Hydrolysis of nucleic acids and procedures for direct estimation of purine and pyrimidine fractions by absorption spectrophotometry. In CHARGAFF E., DAVIDSON J. N. The nucleic acids, vol. 1, 191-199. Acad. Press. N. Y.

MCALLAN A. B., SMITH R. H., 1969. Nucleic acid metabolism in the ruminant. Determination of nucleic acids in digesta. Br. J. Nutr., 23, 671-682.

MCALLAN A. B., SMITH R. H., 1972. Nucleic acids in ruminant digesta as indices of microbial nitrogen. Proc. Nutr. Soc., 31, 24A.

MCALLAN A. B., SMITH R. H., 1973. Degradation of nucleic acid derivatives by rumen bacteria in vitro. Br. J. Nutr., 29, 467-474.

MCALLAN A. B., SMITH R. H., 1983. Estimation of flows of organic matter and nitrogen components in postruminal digesta and effects of level of dietary intake and physical form of protein supplement on such estimates. Br. J. Nutr., 49, 119-127.

MCALLAN A. B., SMITH R. H., 1984. The efficiency of microbial protein synthesis in the rumen and the degradability of feed nitrogen between mouth and abomasum in steers given different diets. Br. J. Nutr., 51, 77-83.

MCDONALD I. W., 1954. The estimation of purines in nucleic acids: a method applicable to materials with low concentration of nucleic acid. Biochem. J., 57, 566-568. 
MATHERS J. C., MiLLER E. L., 1980. A simple procedure using ${ }^{35}$ S incorporation for the measurement of microbial and undegraded food protein in ruminant digesta. Br. J. Nutr., 43, 503-514.

MATHIESON J., 1970. The automated estimation of chromic oxide. Proc. Nutr. Soc., 29, 30 A.

SCHWEINSBERG P. D., TI LI LOO., 1980. Simultaneous analysis of ATP, ADP, AMP, and other purines in human erythrocytes by high-performance liquid chromatography. J. Chromatog., 181, 103-107.

THIVEND P., JOUANY J. P., 1983. Effect of lasalocid sodium on rumen fermentation and digestion in sheep. Reprod. Nutr. Dévelop., 23, 817-828.

TOPPS J. M., ELLIOTT R. C., 1965. Relationship between concentrations of ruminal nucleic acids and excretion of purine derivatives by sheep. Nature. (London), 205, 498-499.

UDEN P., COLUCCI P. E., VAN SOEST P. J., 1980. Investigations of chromium, cerium and cobalt as markers in digesta. Rate of passage studies. J. Sci. Fd. Agric., 31, 625-632.

ZINN R. A., OWENS F. N., 1980. Rapid procedure for quantifying nucleic acid content of digesta, 26-30. In Protein requirements for catt/e. Protein Sympos. Oklahoma State Univ. 